\title{
Review of the Fund's Strategy on Overdue Financial Obligations
}




\section{INTERNATIONAL MONETARY FUND}

\section{IMF POLICY PAPER}

\section{REVIEW OF THE FUND'S STRATEGY ON OVERDUE FINANCIAL OBLIGATIONS}

IMF staff regularly produces papers proposing new IMF policies, exploring options for reform, or reviewing existing IMF policies and operations. The following documents have been released and are included in this package:

- The Staff Report, prepared by IMF staff and completed on July 20, 2017 for the Executive Board's consideration by July 27, 2017.

The IMF's transparency policy allows for the deletion of market-sensitive information and premature disclosure of the authorities' policy intentions in published staff reports and other documents.

Electronic copies of IMF Policy Papers

are available to the public from http://www.imf.org/external/pp/ppindex.aspx

\section{International Monetary Fund Washington, D.C.}




\section{INTERNATIONAL MONETARY FUND}

July 20, 2017

\section{REVIEW OF THE FUND'S STRATEGY ON OVERDUE}

\section{FINANCIAL OBLIGATIONS}

\section{EXECUTIVE SUMMARY}

This paper reviews progress under the Fund's strengthened cooperative strategy on overdue financial obligations. The level of overdue obligations to the Fund declined and their structure has remained broadly unchanged since the last review. Total overdue obligations to the Fund at end-June 2017 amounted to SDR 1,205.7 million, a decline of about SDR 100 million from the end-June 2012 level, when the strategy was reviewed last.

All overdue obligations to the Fund at end-June 2017 were due to two protracted overdue obligations cases. Sudan accounts for the bulk of the overdue obligations to the Fund (80 percent), and Somalia for the remainder. Zimbabwe, which was in protracted overdue obligations to the PRGT at the time of the last Review, settled its overdue obligations to the PRGT on October 20, 2016.

Sudan and Somalia have made efforts to strengthen cooperation with the Fund on policies and payments during the period under review:

Somalia's relations with the Fund were re-established in April 2013. Since then, the Fund and Somalia's authorities have been engaged through Article IV surveillance and two consecutive 12-month SMPs approved in May 2016 and June 2017. Somalia has made no payments to the Fund during the period under review.

Sudan's payments continued to exceed its new obligations falling due and the level of payments at the last review despite the secession of South Sudan in 2011 and the subsequent loss of oil revenue.

It is proposed that the availability of the rights approach be extended by five years, to end-August 2022. The rights approach remains an important option for overdue obligations clearance for the remaining two eligible members (Somalia and Sudan). A decision is proposed to extend the availability of the rights approach.

The Fund's strategy on overdue obligations remains broadly effective in dealing with both short-term and protracted overdue obligations. No changes to the strategy are proposed at this time. 


\section{Approved By}

Sean Hagan,

Andrew Tweedie, and Hugh Bredenkamp
Prepared by Finance, Legal, and Strategy, Policy, and Review Departments

\section{CONTENTS}

INTRODUCTION

RECENT DEVELOPMENTS

A. Overview

B. Recent Reviews of Protracted Overdue Obligations Cases

EXTENSION OF THE RIGHTS APPROACH $\underline{12}$

PROGRESS UNDER THE FUND'S OVERDUE OBLIGATIONS STRATEGY $\underline{13}$

\section{BOXES}

1. The Burden-Sharing Mechanism

2. Currency Valuation Adjustments - CVA

3. Determinants of Overdue Obligations and Their Duration $\underline{11}$

\section{FIGURES}

1. Overdue Financial Obligations to the Fund $\underline{3}$

2. Overdue Financial Obligations by Member $\underline{4}$

3. Members in Short-Term and Protracted Overdue Financial Obligations $-1$

\section{TABLES}

1. Overdue Financial Obligations to the Fund, 2012-17

2. Overdue Financial Obligations to the Fund and Other International Financial Insitutions $\underline{6}$

3. Remedial Measures Applied to Countries in Protracted Overdue Obligations to the Fund__ 14

4. Overdue Financial Obligations to the Fund by Duration, 1981-2017___ $\frac{15}{16}$

5. Overdue Financial Obligations to the Fund by Type, 1981-2017___ 16

6. Number of Countries Incurring Late Payments to the Fund, 2000-17___

7. Countries with Protracted Overdue Financial Obligations to the Fund ___ $\underline{18}$

8. Financial Obligations Falling Due \& Payments to the Fund by Protracted Overdue Obligations Cases, 2012-17

9. Deferred GRA Charges of Countries with Protracted Overdue Obligations, FY 2012-17 __

10. Countries with Overdue Currency Valuation Adjustments ____ 21

\section{ANNEXES}

I. Overdue Financial Obligations to the General Department and the SDR Department-Timetable of Remedial Measures

II. Overdue Financial Obligations to the Poverty Reduction and Growth Trust (PRGT) — Timetable of Remedial Measures 


\section{INTRODUCTION}

1. This paper reviews progress under the Fund's strengthened cooperative strategy on overdue financial obligations since the last review. ${ }^{1}$ Section II presents an overview of overdue financial obligations at end-June 2017, and the recent reviews of the protracted overdue obligations cases. Section III discusses the rights approach and proposes to extend the availability of the rights approach to end-August 2022. Section IV discusses progress under the Fund's strategy on overdue obligations and proposes a decision to complete the Review.

\section{RECENT DEVELOPMENTS}

\section{A. Overview}

\section{Total overdue obligations to the Fund amounted to SDR 1,205.7 million at} end-June 2017. They declined by nearly SDR 100 million since the last review, reflecting payments by Sudan and Zimbabwe (Figure 1 and Table 1). ${ }^{2}$ Most of the overdue obligations to the Fund (about 92 percent) were to the General Resources Account (GRA), with the remainder to the Trust Fund (about 8 percent), and the Structural Adjustment Facility (SAF) (about 1 percent).

Figure 1. Overdue Financial Obligations to the Fund 1/ (In millions of SDRs; 1980-end-June 2017)

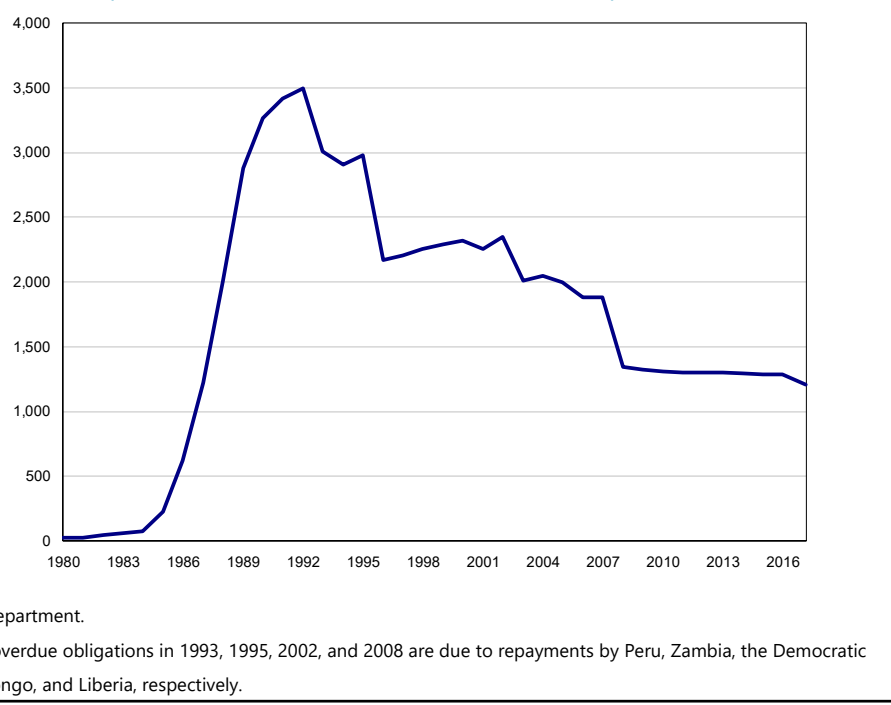

\footnotetext{
1 The last review was concluded in August 2012; see Review of the Fund's Strategy on Overdue Financial Obligations, August 20, 2012; Decision No. 15225-(12/83), adopted August 27, 2012. In April 2015, the Board approved selected streamlining proposals under the FY16-FY18 medium-term budget, changing the periodicity of the review of the Fund's strategy on overdue financial obligations to 5 years or more, as needed. See Selected Streamlining Proposals Under the FY16-FY18 Medium-Term Budget, March 27, 2015, and Decision No. 15764-(15/39), adopted April 23, 2015. Consequently, the deadline to complete the next review of the Fund's strategy on overdue financial obligations was moved to end-August 2017.

${ }^{2}$ Sudan's payments are applied to the overdue principal as per the authorities' instructions.
} 


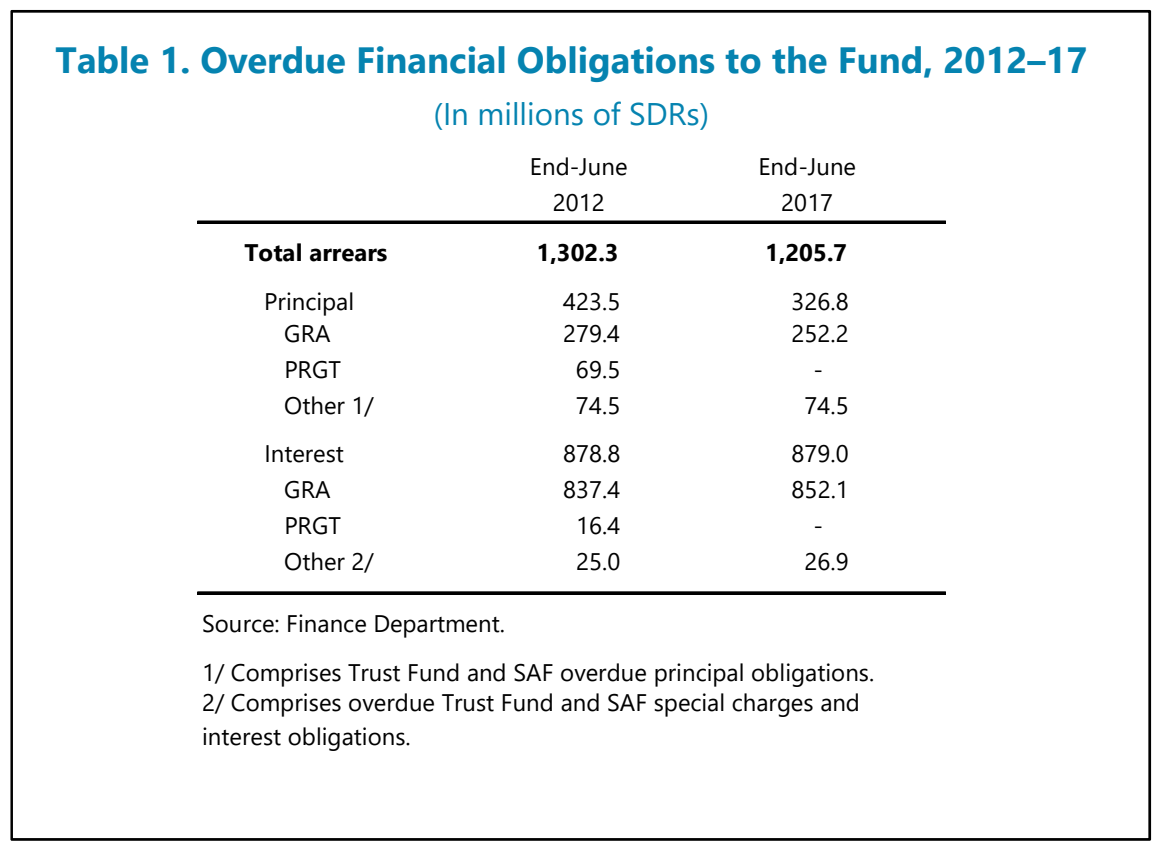

\section{All overdue obligations are accounted for by two members-Somalia and}

Sudan-which remained in protracted overdue obligations to the Fund during the period under review (Table 4). ${ }^{3}$ Somalia and Sudan have accumulated overdue obligations dating back to the mid-1980s, and almost all their overdue obligations (99.9 percent) have been outstanding for six months or longer. These two members account for about 20 and 80 percent of total overdue obligations to the Fund, respectively (Figure 2).

\section{Zimbabwe repaid its overdue obligations to the PRGT using its SDR holdings on October 20,}

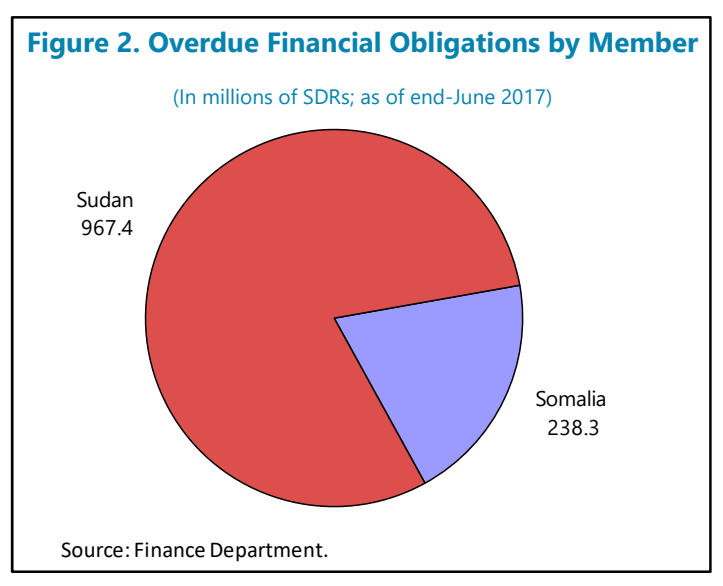

2016. ${ }^{4}$ Zimbabwe had been in continuous overdue obligations to the PRGT since February 2001. The authorities had been making regular monthly payments of US $\$ 0.15$ million since 2013 . The final repayment of SDR 78.3 million was applied towards the PRGT's Reserve Account. This was not accompanied by a normalization of arrears to other international financial institutions. Zimbabwe is in arrears to the World Bank (SDR 844 million as of end-June 2017) and the African Development (AfDB)(SDR 461 million as of end-May 2017). Discussions are ongoing over financing and modalities to clear these obligations.

\footnotetext{
${ }^{3}$ Protracted overdue obligations are those outstanding for six months or more.

${ }^{4}$ Zimbabwe-Settlement of Overdue Financial Obligations to the Poverty Reduction and Growth Trust, Lifting of Declaration of Noncooperation, Lifting of Restriction on Fund Technical Assistance, and Restoration of Poverty Reduction and Growth Trust Eligibility, November 9, 2016.
} 


\section{The repayment allowed for removal of the outstanding remedial measures applied to}

Zimbabwe. These measures were: (i) the declaration of noncooperation with the Fund; (ii) the partial suspension of provision of Fund technical assistance (TA); and (iii) the removal of Zimbabwe from the list of PRGT-eligible countries. In line with the strategy on overdue financial obligations these remedial measures were aimed at encouraging the authorities to make payments to the PRGT and to undertake policies that would enable them to become current on Zimbabwe's financial obligations to the PRGT. The settlement of overdue obligations and lifting of remedial measures constitute a necessary but insufficient step towards Zimbabwe being able to access IMF financing. Zimbabwe must also resolve its arrears to multilateral creditors (including the AfDB, the World Bank, and other multilateral institutions), bilateral official creditors, and external private creditors (if any). ${ }^{5}$ From a policy perspective, strong fiscal adjustment and structural reforms will be crucial to restore fiscal and debt sustainability and foster private sector development.

\section{Overdue financial obligations to the Fund continue to impose a significant financial} cost on the Fund and its membership. The ongoing cost of deferred charges to the GRA is borne by debtor and creditor members through the burden-sharing mechanism, which relies on an adjustment to the rate of charge and the rate of remuneration to make up for the income loss associated with the nonpayment of GRA charges (Box 1). As of end-June 2017, total burden-shared deferred charges amounted to about SDR 718 million, an increase of some SDR 15 million from 2012 (Table 9).

\section{The two members with protracted overdue financial obligations to the Fund have also} accumulated arrears to other international financial institutions (Table 2). As of end-June 2017, their arrears to the World Bank amounted to SDR 863 million—an increase of SDR 241 million (39 percent) since the last review. Arrears to the AfDB amounted to SDR 313 million; an increase of SDR 51 million (20 percent) since the last review. No payments were made to either of these institutions by the members with protracted overdue obligations during the period under review with the exception of a token payment by Sudan to the AfDB.

\footnotetext{
${ }^{5}$ For the Fund's policies on arrears to multilateral creditors and external private creditors, see Sovereign Debt Restructuring-Recent Developments and Implications for the Fund's Legal and Policy Framework, April 26, 2013, Annex I, paragraphs 8-13; for the Fund's policy on arrears to official bilateral official creditors, see Reforming the Fund's Policy on Non-Toleration of Arrears to Official Creditors, October 15, 2015, and the Chairman's Summing Up-Reforming the Fund's Policy on Non-Toleration of Arrears to Official Creditors, December 8, 2015.
} 


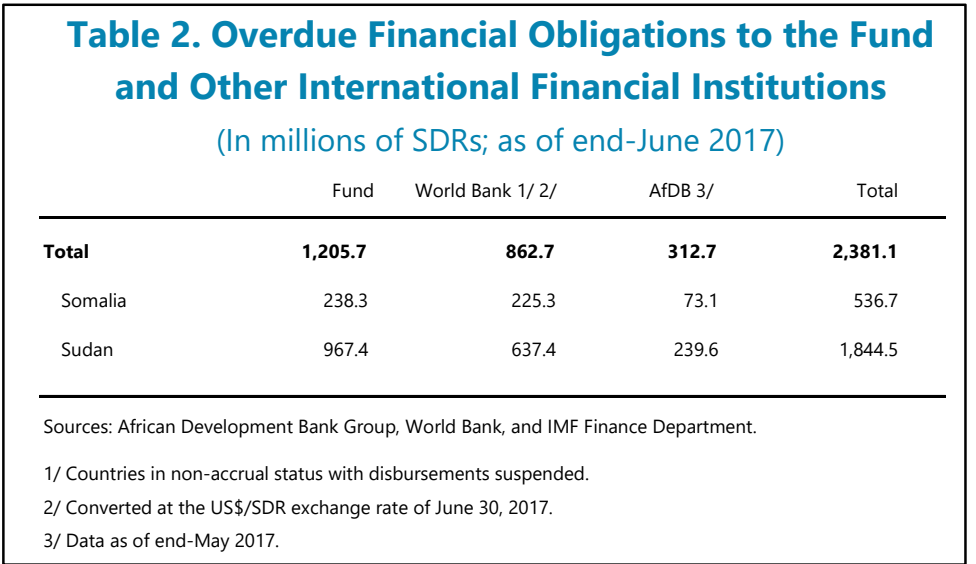

Box 1. The Burden-Sharing Mechanism¹

The burden-sharing mechanism was established in 1986. Since then, it has been used to cover the charges ("deferred charges") due from and unpaid by members with overdue obligations. These charges, if unpaid, would have negative impact on the IMF's income. In addition, until November 1, 2006, resources generated by the burden-sharing mechanism financed the accumulating precautionary balances against possible credit default, in the Special Contingent Account (SCA-1). The Executive Board suspended further accumulation in the SCA-1, effective November $2006 .{ }^{2}$ Currently, burden-sharing is used to cover income losses related to overdue obligations charges due and unpaid by Sudan and Somalia who remain in protracted overdue obligations to the Fund. After deferred charges are settled, equivalent amounts are distributed to members that previously paid higher charges or received reduced remuneration.

Burden sharing of deferred charges is achieved through increases in the rate of charge paid by debtor members and reductions in the rate of remuneration to creditor members. The debtor and creditor members provide equal amounts to cover the charges.

The burden-sharing mechanism has proved essential to continued compliance with International Financial Reporting Standards (IFRS) given the constraints under the IMF Articles of Agreement to make specific loan-loss provisions. Also, from an accounting perspective the SCA-1 offers protection against the risk of loss resulting from the ultimate failure of a member to repay its overdue charges and principal should a member in overdue obligations withdraw from the IMF (or if the IMF is liquidated).

${ }^{1}$ For further information, see: IMF Financial Operations 2016, International Monetary Fund, Washington DC, $2016 ;$ p. 141.

${ }^{2}$ The accumulated balances are to be distributed to contributing members when there are no outstanding overdue obligations or such earlier time as the Fund decides. In March 2008, a partial distribution of SDR 0.5 billion from the SCA-1 account was made in the context of Liberia's debt relief and overdue obligations clearance. For further information on composition of the IMF's precautionary balances, see IMF Financial Operations 2016, International Monetary Fund, Washington DC, 2016; p. 143, Box 6.4 


\section{The incidence of short-term overdue obligations continued a declining trend}

(Figure 3). On average, three members per year incurred short-term overdue obligations (less than six months) since the last review, and only three members were late more than five days. Short-term overdue obligations were mostly incurred due to technical reasons and settled before a formal communication from the Managing Director was called for under the timetable of remedial measures. ${ }^{6}$ In one instance, Greece, the Managing Director briefed the Board about the developments before the deadline envisaged under the timetable of remedial measures due to the gravity of the circumstances and the fact that Directors were informed via the press. In June 2015, Greece "bundled" four payments to facilitate repaying the Fund. The "bundled" repurchases were to be made on June 30, 2015. Nevertheless, the authorities missed the June 30 payment and the subsequent July $13^{\text {th }}$ payment. ${ }^{7,8}$ In both instances staff immediately communicated with the authorities and briefed the Board. ${ }^{9}$ The Managing Director had also participated in the Euro Summit discussions on Greece held in Brussels on July 11-12, 2015. ${ }^{10}$ The Euro Summit acknowledged the importance of ensuring that Greece could clear its overdue obligations to the IMF and the Greek authorities reiterated their unequivocal commitment to honor their financial obligations to all their creditors fully and in a timely manner. ${ }^{11}$ Greece fully settled its overdue obligations to the IMF on July 20, 2015. ${ }^{12}$

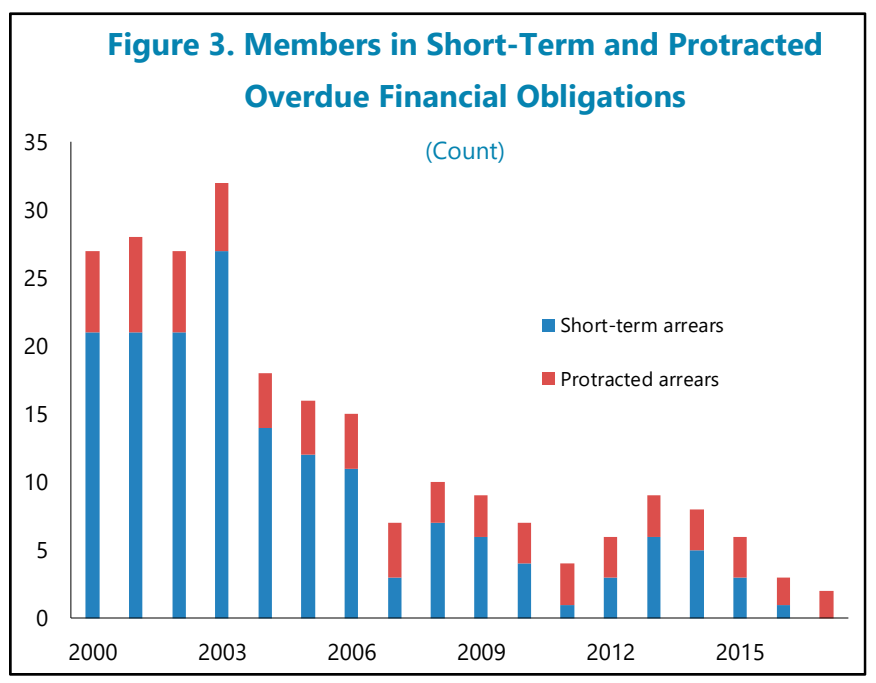

\section{Members with protracted overdue obligations also account for the largest share of} overdue currency valuation adjustments (Table 10). Sudan accounted for 30 percent of the total overdue currency valuation adjustments owed to the Fund. To maintain the value of the Fund's holdings of a member's currency in terms of the SDR, the Fund, at a minimum, adjusts its holdings of the member's currency at the end of each financial year. Such adjustments may result in an obligation by the member to pay additional currency to the Fund, or vice-versa, depending on exchange rate movements (Box 2). While overdue currency valuation adjustments do not generally

\footnotetext{
${ }^{6}$ In accordance with the timetable, a formal communication from the Managing Director to the authorities is called for when an obligation has been outstanding for two weeks and to the Board when a member is overdue in its obligations one month after the emergence of overdue obligations.

${ }^{7}$ Press Release No. 15/310, June 30, 2015.

8 Press Release No. 15/334, July 13, 2015.

${ }^{9}$ Ibidem.

${ }^{10}$ Press Release No. 15/332, July 13, 2015

${ }^{11}$ Euro Summit statement, July 12, 2015, p. 5 and 6.

12 Press Release No. 15/344, July 20, 2015.
} 
affect the Fund's financing capacity, they nevertheless represent an essential element of members' financial obligations to the Fund, and staff actively pursues their settlement.

\section{Box 2. Currency Valuation Adjustments--CVA}

The currency valuation adjustments are part of the IMF's holdings of members' currencies. Currencies held by the IMF are valued in terms of the SDR using each member country's representative rate of exchange. When that exchange rate changes, a member must pay additional currency if their currency depreciates against the SDR and the IMF must refund some of these currency holdings if the currency appreciates. That allows the IMF to maintain, in SDR terms, the value of the balances of the IMF's holdings of its currency unchanged and insulates the IMF's resources from exchange rate fluctuations.

All holdings of a member's currency in the General Resources Account, including any unsettled obligations resulting from an earlier revaluation, are revalued at the new rate. The new rate is applied to all transactions in that currency, including administrative receipts and payments, until the rate is again adjusted. A new rate becomes effective in the IMF's accounts at the close of business on the date of its adjustment.

${ }^{1}$ For further information see: IMF Financial Operations 2016, International Monetary Fund, Washington DC, 2016 ; p. 37.

\section{Since the general SDR allocation on August 28, 2009, members with protracted overdue financial obligations to the Fund have remained current to the SDR Department. ${ }^{13}$} Pursuant to Rule T-2, the accounts of participants in the SDR Department are debited with the amounts of the assessments levied on participants for the expenses of conducting the business of the SDR Department in accordance with Article XX, Section 4. However, SDRs allocated under the special allocation pursuant to the Fourth Amendment to members in protracted overdue obligations are held in escrow accounts in the SDR Department, and will be made available to these members following clearance of their respective overdue obligations.

\section{B. Recent Reviews of Protracted Overdue Obligations Cases ${ }^{14}$}

\section{In the period since June 2012, the record of cooperation with the Fund by the countries with protracted overdue obligations countries has evolved. The remedial measures have remained in place in the two protracted overdue obligations cases.}

\footnotetext{
13 Somalia and Sudan received, respectively, under the general SDR allocation the following amounts: SDR 33 million, SDR 126 million; and SDR 4 million, and SDR 16 million, respectively, under the special SDR allocation.

${ }^{14}$ This section summarizes progress under the Fund's overdue obligations strategy with respect to the protracted overdue obligations cases. Updates of developments in these countries would be provided at the next review of each member's overdue obligations within one year of the date of the last review's decision. For an overview of determinants and duration of overdue obligations, see Box 3 at the end of this section.
} 


\section{Somalia}

12. The Executive Board last reviewed Somalia's overdue financial obligations to the Fund and further review following declaration of ineligibility in February 2017. This was the fifth review conducted since Somalia re-established relations with the Fund following a hiatus of more than two decades, in April 2013. A review was postponed on one occasion to benefit from an on-going policy discussion and to align the review with the Board's discussion of the country matters. The declaration of ineligibility to use the Fund's general resources remains in place (Table 3).

\section{The Executive Board noted that, since the previous review of the overdue financial obligations, the authorities had continued to make progress in strengthening policies and governance, supported by the staff-monitored program which aimed to strengthen} macroeconomic management, rebuild institutions, and improve governance and economic statistics. Going forward, Directors encouraged the authorities to keep up the pace of policy and reform implementation, particularly in fiscal and financial sectors and in preparing the National Development Plan, along with a productive dialogue with the creditor community. In this context, and to facilitate future fund-raising efforts to clear overdue obligations and secure debt relief, the Fund strongly encouraged the authorities to refrain from new external borrowing and to seek external financing only in the form of grants. While recognizing Somalia's difficult economic, political, and security situation, the Fund strongly encouraged Somalia to make regular and timely payments to the Fund in line with its capacity to pay and to increase them as Somalia's payment capacity improves. ${ }^{15}$ The Executive Board will again consider Somalia's overdue financial obligations to the Fund within one year of the date of the review decision adopted on February 3, 2017. ${ }^{16}$

\section{Sudan}

\section{The Executive Board last reviewed Sudan's overdue financial obligations to the Fund} and the Managing Director's complaint with respect to the suspension of Sudan's voting and related rights in December 2016. This was the fifth review conducted since the time of the last review of the strategy on overdue financial obligations, in August 2012. The reviews were postponed on four occasions to benefit from an on-going policy discussions and to align the reviews with the

\footnotetext{
${ }^{15}$ Somalia has been in continuous overdue obligations to the Fund since 1987 and no payments to the Fund have been made since December 1990. In accordance with Executive Board Decision No. 15092-(12/19) adopted February 24, 2012, owing to Somalia's overdue repurchase obligations to the GRA, Somalia's share in the distribution of the general reserve attributed to windfall gold sale profits was made in Somalia's own currency and was attributed to Fund holdings of Somalia's currency subject to repurchase. This reduced Somalia's overdue financial obligations to the Fund in 2012 and 2013.

16 The reviews are conducted yearly following the Board's approval in April 2015 of selected streamlining proposals under the FY16-FY18 medium-term budget, changing the periodicity of the review of the overdue financial obligations by country to one year. See Selected Streamlining Proposals Under the FY16-FY18 Medium-Term Budget, March 27, 2015, and Decision No. 15764-(15/39), adopted April 23, 2015.
} 
Board's discussion of country matters. The complaint with respect to the suspension of Sudan's voting and related rights remains in place (Table 3 ).

15. The Executive Board noted that Sudan's economic situation deteriorated sharply in the aftermath of South Sudan's secession, but was encouraged that economic performance had so far improved. Addressing the challenges that followed the secession would require accelerating policy consolidation and reform to achieve macroeconomic stability, address vulnerabilities, and promote inclusive growth.

\section{The Executive Board noted the extension of the "zero-option" 17 and encouraged the} authorities to continue to reach out to their creditors to elicit support for debt relief. In that context, the Board underscored that it is important to avoid selective debt servicing to bilateral creditors as this may complicate reaching agreement with these creditors on a debt resolution strategy.

\section{The Executive Board urged the authorities to continue to strengthen cooperation with}

the Fund. They welcomed the payments received in 2016 so far and the authorities' commitment to a minimum payment of US $\$ 10$ million to the Fund per year, and strongly encouraged them to make payments to the Fund that were at least sufficient to cover obligations falling due, to make payments regularly, and to increase them as Sudan's payment capacity improves. ${ }^{18}$ The Executive Board will again consider Sudan's overdue financial obligations to the Fund and the Managing Director's complaint with respect to the suspension of Sudan's voting and related rights in the Fund within twelve months of the date of this decision adopted on December 15, 2016. ${ }^{19}$

\footnotetext{
17 The so-called "zero-option" is a 2012 agreement between Sudan and South Sudan whereby Sudan would retain all the external liabilities after the secession of South Sudan, if the international community gave firm commitments to the delivery of debt relief within two years. Absent such commitment, Sudan's external debt would be apportioned with South Sudan based on a formula (to be determined). This deadline has been extended two times.

18 In accordance with Executive Board Decision No. 15092-(12/19) adopted February 24, 2012, owing to Sudan's overdue repurchase obligations to the GRA, Sudan's share in the distribution of the general reserve attributed to windfall gold sale profits was made in Sudan's own currency and was attributed to Fund holdings of Sudan's currency subject to repurchase. This reduced Sudan's overdue financial obligations to the Fund in 2012 and 2013.

19 The reviews are conducted yearly following the Board's approval in April 2015 of selected streamlining proposals under the FY16-FY18 medium-term budget, changing the periodicity of the review of the overdue financial obligations by country to one year. See Selected Streamlining Proposals Under the FY16-FY18 Medium-Term Budget, March 27, 2015, and Decision No. 15764-(15/39), adopted April 23, 2015.
} 
Box 3. Determinants of Overdue Obligations and Their Duration ${ }^{1}$

Recent research on determinants of overdue obligations to the Fund suggests the causes of overdue obligations are multifaceted and encompass both economic and political factors. Among the economic factors the most important determinants of overdue obligations are previous overdue obligations, reserves coverage of imports, and institutional quality. The political developments, including civil unrest, make overdue obligations more likely to arise and to last longer.

On average, a country with overdue obligations would have worse macroeconomic outcomes-debt, inflation, international reserves, growth, and welfare-than a country without overdue obligations. The protracted overdue obligations countries performed worse than the ones with short-term overdue obligations. They suffered much higher incidences of civil unrest that the two other groups and their institutional quality ratings have been much worse. They have (not surprisingly) accumulated more credit outstanding to the IMF than other countries.

At a time of clearance of protracted overdue obligations, the macroeconomic outcomes in protracted overdue obligations countries approximated the outcomes in the sort-term overdue obligations countries. The civil unrest incidence dropped as well but remained somewhat elevated compared to the short-term overdue obligations cases.

For protracted overdue obligations, severe political crises are the most common cause. As triggers of protracted overdue obligations, the political factors (e.g., wars, political acts, etc.) have been present on their own or have interlinked with global factors (e.g., commodity price swings, weather events, or a debt crisis affecting potentially all economies and beyond individual control), and country-specific (e.g., corruption, poor policy implementation, etc.) factors.

The estimated probabilities of overdue obligations occurrence are small and declining over time for countries with outstanding Fund credit. This is owing to the improved political environment and the macroeconomic environment that changed for the better since 1980s.

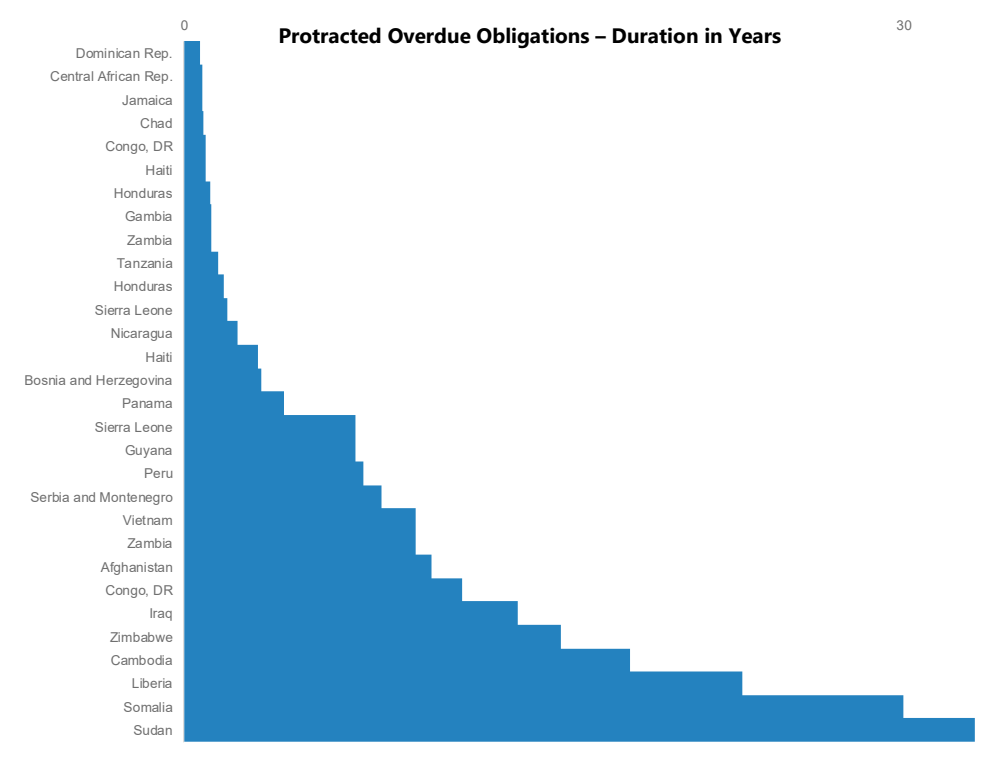

\section{Solving protracted overdue} obligations cases can take a long time. The remaining two protracted overdue obligations cases are fragile countries. For that group of countries, the research suggests that real GDP growth and civil unrest have been the most important determinants of the persistence of protracted overdue obligations. This suggests that the clearance of protracted overdue obligations will require a decisive turnaround of political fortunes in addition to a lasting change on the macroeconomic front.

1See: Anne Oeking and Mariusz

Sumlinski, "Arrears to the IMF - A Ghost of the Past?", IMF Working Paper 16/225, International Monetary Fund, 2016. 


\section{EXTENSION OF THE RIGHTS APPROACH}

18. The rights approach helps eligible members with overdue obligations to the Fund to establish a track record of cooperation on policies with the Fund by undertaking an economic program with conditionality equivalent to that of upper credit tranche Fund arrangements. ${ }^{20}$ The member is also expected to make payments to the Fund (and the World Bank) that, at a minimum, are sufficient to meet new obligations falling due. ${ }^{21}$ By establishing such a track record, the member accumulates "rights" to future drawings of Fund resources following the clearance of its overdue financial obligations and upon approval of a successor arrangement by the Fund. At the end of the rights accumulation program, bilateral creditors would provide a bridge loan to clear the member's overdue obligations to the Fund, which would be followed by the member's access to new Fund financing.

19. The rights approach remains an important option for overdue obligations clearance for Somalia and Sudan-the two members that remain eligible. The rights approach was initiated in 1990 and used in the 1990s to clear the overdue obligations to the Fund of three members-Peru, Sierra Leone, and Zambia. Eligibility for the rights approach was restricted to the eleven members that had protracted overdue obligations to the Fund at end-1989. Of these countries, only Somalia and Sudan remain eligible for the rights approach. Use of the rights approach is not required for these members, but it could provide a useful approach for overdue obligations clearance considering country-specific circumstances.

\section{The availability of the rights approach has been extended on several occasions, most} recently in August 2015. ${ }^{22}$ The availability of the rights approach was extended to end-August 2017, to maintain availability of the rights approach for potential overdue obligations clearance for Somalia and Sudan-the remaining two eligible members-and to align the Board's consideration of the extension of the availability of the rights approach with the review of the Fund's overdue obligations strategy. ${ }^{23}$

21. Staff proposes to extend the availability of the rights approach to end-August 2022. This extension would maintain the availability of the rights approach for potential overdue obligations clearance for Somalia and Sudan and align the Board's consideration of the extension of

\footnotetext{
20 Summing Up by the Chairman-Operational Modalities of the Rights Approach June 22, 1990.

${ }^{21}$ While Rights Accumulation Programs involve upper credit tranche conditionality, they require modified financing assurances in the sense that overdue obligations to the IMF (and possibly to other multilateral institutions) can remain outstanding during the program period, although members are expected to make maximum efforts to reduce their overdue financial obligations to the IMF.

22 Decision No. 15853-(15/80), adopted August 4, 2015.

23 In April 2015, the Board approved selected streamlining proposals under the FY16-FY18 medium-term budget, changing the periodicity of the review of the Fund's strategy on overdue financial obligations to 5 years or more, as needed. Consequently, the deadline to complete the next review of the Fund's strategy on overdue financial obligations was moved to end-August 2017. See Selected Streamlining Proposals Under the FY16-FY18 Medium-Term Budget, March 27, 2015, and Decision No. 15764-(15/39), adopted April 23, 2015.
} 
the availability of the rights approach with the reviews of the Fund's overdue obligations strategy, which are to be conducted every five years or more, as needed. A proposed decision is included to this effect.

\section{PROGRESS UNDER THE FUND'S OVERDUE OBLIGATIONS STRATEGY}

22. The Fund's strategy on overdue obligations has remained broadly effective in dealing with cases that have arisen to date. No changes to the strategy are proposed at this time. The strategy is comprised of three elements: prevention, intensified collaboration (including the rights approach), and remedial measures. The preventive element of the strategy has generally worked well in avoiding new overdue obligations, or in bringing about the quick clearance of such overdue obligations should they occur, thereby preventing new cases of protracted overdue obligations. The timetables for remedial measures for overdue financial obligations to the Fund's General and SDR Departments and the PRGT are provided in Annexes I and II. 


\begin{tabular}{|c|c|c|c|c|c|c|c|}
\hline & $\begin{array}{l}\text { In Continuous } \\
\text { Arrears Since }\end{array}$ & $\begin{array}{l}\text { Complaint Issued } \\
\text { (Noted) }\end{array}$ & $\begin{array}{l}\text { Declaration of } \\
\text { Ineligibility }\end{array}$ & $\begin{array}{l}\text { Declaration of } \\
\text { Noncooperation }\end{array}$ & $\begin{array}{l}\text { Suspension of } \\
\text { Voting Rights }\end{array}$ & $\begin{array}{c}\text { Complaint for } \\
\text { Compulsory } \\
\text { Withdrawal }\end{array}$ & \\
\hline Somalia & $7 / 2 / 87$ & $\begin{array}{c}9 / 8 / 87 \\
(9 / 15 / 87)\end{array}$ & $5 / 6 / 88$ & & & & \\
\hline Sudan & $7 / 12 / 84$ & $\begin{array}{c}12 / 12 / 84 \\
(1 / 9 / 85) \\
1 / 22 / 97 \\
(1 / 24 / 97)\end{array}$ & $2 / 3 / 86$ & $\begin{array}{c}9 / 14 / 1990 \\
\text { lifted on } 8 / 27 / 99\end{array}$ & $\begin{array}{c}8 / 9 / 1993 \\
\text { lifted on } 8 / 1 / 00\end{array}$ & 4/8/1994 & 21 \\
\hline
\end{tabular}

Source: Finance Department.

1/ Remedial measures are applied to overdue financial obligations to the General Resources Account (GRA), the SDR Department, and to the Poverty Reduction and Growth Trust (PRGT). With respect to the GRA and the SDR Departments, a complaint is issued by the Managing Director when a member falls into overdue obligations to the Fund for two months or more. In the GRA, depending on the persistence in failure of a member to fulfill its obligations, the complaint may lead to several different sanctions under Article XXVI, Section 2: declaration of ineligibility to use Fund resources, suspension of voting rights in the Fund, and compulsory withdrawal from the Fund. Regarding SDR Department, Article XXVI, Section 2(f) provides that Article XXVI, Section 2 sanctions shall not apply to failure to fulfill any obligations with respect to SDRs. Rather, the right of a participant to use SDRs may be suspended as provided for under Article XXIII, Sections 2(a) and (b). Overdue obligations to the PRGT are not breaches of obligations under the Articles and are thus not subject to Article XXVI sanctions. Remedial measures for dealing with PRGT overdue obligations include removal from the list of

PRGT-eligible countries, declaration of noncooperation and suspension of technical assistance. The Fund also levies the SDR interest rate on any amounts of any overdue interest on, or overdue repayments of, Trust loans.

2/ Considering the lifting of the suspension of Sudan's voting rights on 8/1/2000, the complaint for the compulsory withdrawal of Sudan has been reformulated as a complaint for the suspension of Sudan's voting rights.

3/ Complaint withdrawn on February 12, 1997, following clearance of overdue obligations in the SDR Department. 
Table 4. Overdue Financial Obligations to the Fund by Duration, 1981-2017 (In millions of SDRs; end of period)

\begin{tabular}{rcrrrr}
\hline \multirow{2}{*}{ Year } & No. of & \multicolumn{3}{c}{ Duration } & \multicolumn{1}{c}{$\begin{array}{c}\text { Total } \\
\text { Amount }\end{array}$} \\
\cline { 3 - 5 } & & Countries & 0-1 month & $1-6$ months & $\begin{array}{c}\text { 6 months } \\
\text { or more }\end{array}$ \\
\hline 1981 & 20 & 6.3 & 5.2 & 22.9 & 34.4 \\
1990 & 15 & 24.5 & 211.7 & $3,184.6$ & $3,420.8$ \\
2000 & 9 & 0.6 & 31.5 & $2,210.2$ & $2,242.9$ \\
2001 & 13 & 6.9 & 58.5 & $2,253.8$ & $2,318.6$ \\
2002 & 7 & 5.6 & 45.4 & $1,948.1$ & $1,999.3$ \\
2003 & 9 & 3.0 & 26.4 & $2,010.5$ & $2,040.4$ \\
2004 & 7 & 3.5 & 21.1 & $1,974.0$ & $1,999.0$ \\
2005 & 4 & 1.5 & 14.1 & $1,882.6$ & $1,898.3$ \\
2006 & 6 & 3.0 & 16.7 & $1,877.9$ & $1,897.7$ \\
2007 & 4 & 1.9 & 16.7 & $1,873.1$ & $1,892.5$ \\
2008 & 3 & 1.2 & 6.7 & $1,318.0$ & $1,325.9$ \\
2009 & 3 & 0.3 & 2.0 & $1,308.0$ & $1,310.3$ \\
2010 & 3 & 0.3 & 1.9 & $1,306.0$ & $1,308.3$ \\
2011 & 3 & 0.3 & 2.1 & $1,303.9$ & $1,306.4$ \\
2012 & 3 & 0.2 & 1.5 & $1,298.4$ & $1,300.1$ \\
2013 & 3 & 0.2 & 1.5 & $1,295.6$ & $1,297.3$ \\
2014 & 3 & 1.1 & 1.5 & $1,290.7$ & $1,293.2$ \\
2015 & 3 & 0.2 & 1.4 & $1,287.3$ & $1,288.9$ \\
2016 & 2 & 10.9 & 1.4 & $1,204.2$ & $1,216.5$ \\
June, 2017 & 2 & 0.2 & 1.7 & $1,203.9$ & $1,205.7$ \\
\hline
\end{tabular}

Source: Finance Department. 


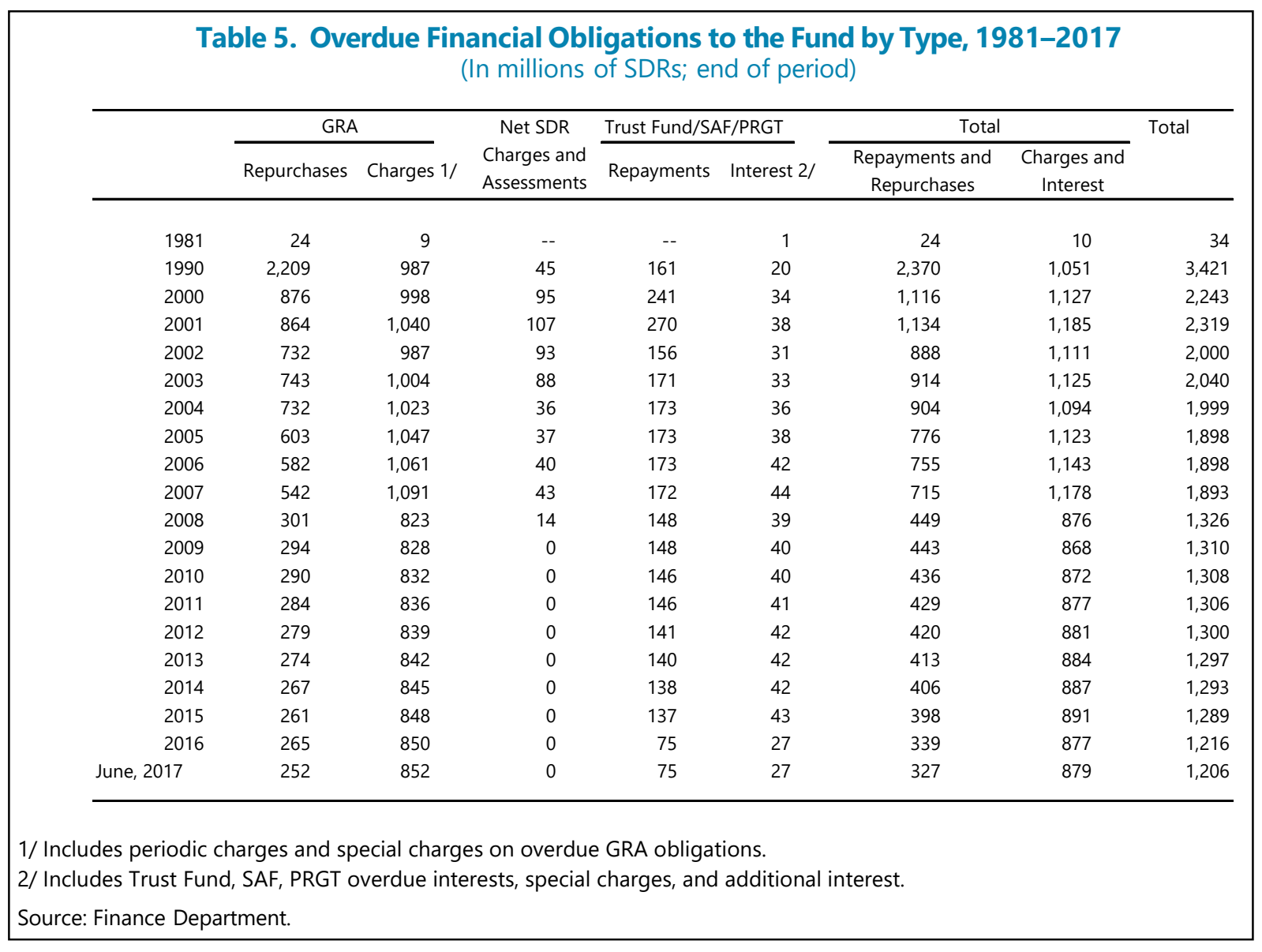


Table 6. Number of Countries Incurring Late Payments to the Fund, 2000-17

$20002005201020112012 \quad 2013201420152016$

$\begin{array}{lllllllllll}2000 & 2005 & 2010 & 2011 & 2012 & 2013 & 2014 & 2015 & 2016 & 2017 & 1 /\end{array}$

Number of members with obligations

falling due during the period $2 /$

$\begin{array}{llllllllll}164 & 159 & 186 & 187 & 188 & 188 & 188 & 188 & 189 & 189\end{array}$

Number of members with late payments during the period $3 /$

Of which:

Protracted cases 4/

6

43

3

3

3

3

2

2

Number of members with late payments

as a percent of number of members with

obligations falling due during the period

$\begin{array}{llllllllll}16.5 & 10.1 & 3.8 & 2.1 & 3.2 & 4.8 & 4.3 & 3.2 & 1.6 & 1.1\end{array}$

Source: Finance Department.

1/ Six months to June 30, 2017.

2/ Includes all types of financial obligations falling due to the Fund. Members with multiple obligations falling due during the period are counted only once.

3/ Members paying late during the period or with obligations overdue at the end of the period are counted only once.

4/ Members with overdue obligations outstanding for six months or more at end of period. 
Table 7. Countries with Protracted Overdue Financial Obligations to the Fund 1/ (As of end-June 2017)

\begin{tabular}{lrrrrrr}
\hline & \multicolumn{2}{c}{ Total Indebtedness 2/ } & & \multicolumn{2}{c}{ Of which: Overdue (SDR millions) } \\
\cline { 2 - 3 } \cline { 5 - 6 } \cline { 5 - 6 } & (SDR millions) & (\% of quota) & & Principal & Interest & Total \\
\hline \multirow{2}{*}{ Somalia } & 238.3 & 539.0 & & 111.5 & 126.7 & 238.3 \\
Sudan & 967.4 & 570.0 & & 215.2 & 752.2 & 967.4 \\
Total & $\mathbf{1 , 2 0 5 . 7}$ & & & $\mathbf{3 2 6 . 8}$ & $\mathbf{8 7 9 . 0}$ & $\mathbf{1 , 2 0 5 . 7}$ \\
\hline
\end{tabular}

Source: Finance Department.

1/ Countries with overdue obligations outstanding for six months or more.

2/ Includes outstanding repurchases, SAF, PRGT and Trust Fund loans, and overdue charges and interest (including special charges). 
Table 8. Financial Obligations Falling Due \& Payments to the Fund by Protracted Overdue Obligations Cases, 2012-17 1/

(In millions of SDRs)

\begin{tabular}{lcccr}
\hline & Somalia & Sudan & Zimbabwe 2/ & Total \\
\hline $\begin{array}{l}\text { Obligations falling due } \\
2012\end{array}$ & 1.2 & 2.4 & 0.2 & \\
2013 & 1.1 & 2.3 & 0.1 & 3.9 \\
2014 & 1.2 & 2.3 & 0.2 & 3.6 \\
2015 & 1.1 & 2.1 & 0.1 & 3.3 \\
2016 & 1.1 & 2.0 & 0.1 & 3.3 \\
Jan.-June 2017 & 0.7 & 1.3 & 0.4 & 2.4 \\
Payments made to the Fund 3/ & & & & \\
2012 & 0.0 & 4.4 & 5.1 & 9.5 \\
2013 & 0.0 & 3.6 & 1.3 & 4.9 \\
2014 & 0.0 & 7.1 & 1.5 & 8.6 \\
2015 & 0.0 & 5.4 & 1.4 & 6.8 \\
2016 & 0.0 & 7.2 & 79.2 & 86.4 \\
Jan.-June 2017 & 0.0 & 1.9 & 0.4 & 2.4 \\
Payments made as percent & & & & \\
of obligations falling due & & & & \\
2012 & 3.0 & 179.5 & 2348.4 & 246.4 \\
2013 & 1.9 & 156.7 & 982.5 & 138.3 \\
2014 & 2.3 & 312.7 & 823.7 & 238.0 \\
2015 & 1.4 & 257.4 & 1461.2 & 206.3 \\
2016 & 1.6 & 352.2 & 69333.4 & 2645.1 \\
Jan.-June 2017 & 6.3 & 153.3 & 100.0 & 100.3 \\
\hline
\end{tabular}

Source: Finance Department.

$1 /$ Includes payments to the Fund, quarterly net SDR charges, and annual SDR assessment charges. Amounts of 0.0 are less than SDR 50,000

2/ As of October 2016, Zimbabwe no longer has any overdue obligations. For 2016, the large ratio of payments made to obligations falling due is owing to Zimbabwe's repayment of a remainder of its overdue obligations to the PRGT.

3/ Amounts exclude payments attributed to overdue obligations from the partial distribution of the General Reserve attributed to windfall gold sales profits in 2012 and 2013. In accordance with Executive Board Decision No. 15092-(12/19) adopted

February 24, 2012, owing to Somalia's and Sudan's overdue repurchase obligations to the GRA, Somalia's and Sudan's share in the distribution of the general reserve attributed to windfall gold sale profits was made in Somalia's own currency and in Sudan's own currency and was attributed to Fund holdings of Somalia's currency and Sudan's currency subject to repurchase. 


\begin{tabular}{|c|c|c|c|c|c|c|c|c|c|c|c|c|c|}
\hline \multicolumn{14}{|c|}{$\begin{array}{l}\text { Table 9. Deferred GRA Charges of Countries with Protracted Overdue Obligations, FY 2012-17 1/ } \\
\text { (In millions of SDRs, as of June 30, 2017) }\end{array}$} \\
\hline & \multirow{2}{*}{$\begin{array}{c}\text { FY } 2012 \\
\text { Balance } \\
\text { Apr. 30, } \\
2012 \\
\end{array}$} & \multicolumn{2}{|c|}{ FY 2013} & \multicolumn{2}{|c|}{ FY 2014} & \multicolumn{2}{|c|}{ FY 2015} & \multicolumn{2}{|c|}{ FY 2016} & \multicolumn{2}{|c|}{ FY 2017} & \multicolumn{2}{|c|}{ FY 2018} \\
\hline & & $\begin{array}{l}\text { Period } \\
\text { deferrals }\end{array}$ & $\begin{array}{l}\text { Balance } \\
\text { Apr. 30, } \\
2013 \\
\end{array}$ & $\begin{array}{c}\text { Period } \\
\text { deferrals }\end{array}$ & $\begin{array}{l}\text { Balance } \\
\text { Apr. } 30, \\
2014 \\
\end{array}$ & $\begin{array}{c}\text { Period } \\
\text { deferrals }\end{array}$ & $\begin{array}{l}\text { Balance } \\
\text { Apr. 30, } \\
2015 \\
\end{array}$ & $\begin{array}{l}\text { Period } \\
\text { deferrals }\end{array}$ & $\begin{array}{l}\text { Balance } \\
\text { Apr. 30, } \\
2016 \\
\end{array}$ & $\begin{array}{l}\text { Period } \\
\text { deferrals }\end{array}$ & $\begin{array}{l}\text { Balance } \\
\text { Apr. 30, } \\
2017 \\
\end{array}$ & $\begin{array}{l}\text { Period } \\
\text { deferrals }\end{array}$ & $\begin{array}{c}\text { Balance } \\
\text { June } 30, \\
2017\end{array}$ \\
\hline \multicolumn{14}{|l|}{ Somalia } \\
\hline All charges & 118.2 & 1.1 & 119.3 & 1.1 & 120.3 & 1.0 & 121.4 & 1.0 & 122.4 & 1.1 & 123.5 & 0.2 & 123.8 \\
\hline Burden shared & 111.8 & 1.1 & 112.8 & 1.1 & 113.9 & 1.0 & 114.9 & 1.0 & 115.9 & 1.1 & 117.1 & 0.2 & 117.3 \\
\hline \multicolumn{14}{|l|}{ Sudan } \\
\hline All charges & 719.2 & 2.0 & 721.2 & 2.0 & 723.1 & 1.8 & 725.0 & 1.7 & 726.7 & 1.9 & 728.6 & 0.4 & 729.0 \\
\hline Burden shared & 591.3 & 2.0 & 593.3 & 2.0 & 595.3 & 1.8 & 597.1 & 1.7 & 598.8 & 1.9 & 600.7 & 0.4 & 601.1 \\
\hline \multicolumn{14}{|l|}{$\begin{array}{l}\text { Total } \\
\text { All charges }\end{array}$} \\
\hline All charges & 837.4 & 3.0 & 840.5 & 3.0 & 843.5 & 2.8 & 846.3 & 2.8 & 849.1 & 3.0 & 852.1 & 0.7 & 852.8 \\
\hline Burden shared & 703.1 & 3.0 & 706.1 & 3.0 & 709.2 & 2.8 & 712.0 & 2.8 & 714.8 & 3.0 & 717.8 & 0.7 & 718.4 \\
\hline
\end{tabular}


Table 10. Countries with Overdue Currency Valuation Adjustments 1/

(In millions of SDRs)

\begin{tabular}{lr}
\hline Member & $\begin{array}{r}\text { Balance as of } \\
\text { June 30, 2017 }\end{array}$ \\
\hline Afghanistan & 45.5 \\
Angola & 230.1 \\
Brunei & 7.3 \\
Congo, Dem. Rep. & 346.0 \\
Madagascar & 7.5 \\
Palau & 0.1 \\
Papua New Guinea & 17.3 \\
South Sudan & 239.3 \\
Sudan 2/ & 414.4 \\
Suriname & 80.0 \\
Tuvalu & 0.2 \\
Total & $1,387.7$ \\
\hline
\end{tabular}

Source: Finance Department.

1/ The Fund revalues members' currencies at least annually, at the end of the Fund's financial year (April 30). Members are notified of the adjustments arising from the revaluation. Settlement of adjustments shall be made promptly after the end of the financial year and at other times requested by the Fund or the member. Adjustments are payable in local currency and are not included among overdue obligations. This table lists members whose currency valuation adjustments payable from April 30, 2016 had not been settled as of end-June 2017 as well as the cumulative adjustments payable as of June 30, 2017.

2/ Sudan: Adjustments have been outstanding since the end of FY1996. 


\section{Annex I. Overdue Financial Obligations to the General Department and the SDR Department Timetable of Remedial Measures ${ }^{1}$}

\begin{tabular}{|c|c|}
\hline Time after emergence of arrears & Action \\
\hline Immediately & $\begin{array}{l}\text { Staff sends a cable urging the member to make the payment promptly; this } \\
\text { communication is followed up through the office of the concerned Executive } \\
\text { Director. The member is not permitted any use of the Fund's resources nor is any } \\
\text { request for the use of Fund resources placed before the Executive Board until the } \\
\text { arrears are cleared. }\end{array}$ \\
\hline 2 weeks & $\begin{array}{l}\text { Management sends a communication to the Governor for the member stressing } \\
\text { the seriousness of the failure to meet obligations and urging full and prompt } \\
\text { settlement. }\end{array}$ \\
\hline 1 month & $\begin{array}{l}\text { The Managing Director notifies the Executive Board that an obligation is } \\
\text { overdue. }\end{array}$ \\
\hline 6 weeks & $\begin{array}{l}\text { The Managing Director notifies the member that unless the overdue obligations } \\
\text { are settled promptly a complaint will be issued to the Executive Board. The } \\
\text { Managing Director would also consult with and recommend to the Executive } \\
\text { Board that a communication concerning the member's situation should be sent } \\
\text { to selected Fund Governors or to all Fund Governors in the event that the } \\
\text { member has not improved its cooperation with the Fund. }\end{array}$ \\
\hline 2 months & $\begin{array}{l}\text { A complaint regarding the member's overdue obligations is issued by the } \\
\text { Managing Director to the Executive Board. }\end{array}$ \\
\hline 3 months & $\begin{array}{l}\text { A brief factual statement noting the existence and amount of arrears is posted } \\
\text { on the Fund's external website, and will be updated as necessary. It also indicates } \\
\text { that the member's access to the Fund, including PRGT and HIPC resources, has } \\
\text { been and will remain suspended for as long as arrears remain outstanding. The } \\
\text { complaint is given substantive consideration by the Executive Board. The Board } \\
\text { has usually decided to limit the member's use of the general resources and, if } \\
\text { overdue SDR obligations are involved, suspend its right to use SDRs. A press } \\
\text { release is issued following the Board's decision to limit the member's use of the } \\
\text { general resources or, if the member has overdue obligations in the SDR } \\
\text { Department, to suspend its right to use SDRs. A similar press release will be } \\
\text { issued following a decision to lift such limitation or suspension. }\end{array}$ \\
\hline $6-12$ months & $\begin{array}{l}\text { The Executive Board will review its decision on limitation within three months, } \\
\text { with the possibility of a second review if warranted. Depending on the Executive } \\
\text { Board's assessment of the specific circumstances and of the efforts being made } \\
\text { by the member to fulfill its obligations to the Fund, a declaration of ineligibility } \\
\text { will be considered to take effect not more than twelve months after the }\end{array}$ \\
\hline & $\begin{array}{l}\text { emergence of arrears. The sending of communications to all Fund Governors and } \\
\text { the heads of selected international financial institutions regarding the member's } \\
\text { continued failure to fulfill its financial obligations to the Fund is to be considered } \\
\text { at the same time as the declaration of ineligibility. }\end{array}$ \\
\hline Up to 15 months & $\begin{array}{l}\text { A declaration of noncooperation will be considered within three months after } \\
\text { the dispatch of the communications. Upon a declaration of noncooperation, } \\
\text { technical assistance to the member will be suspended unless the Executive Board } \\
\text { decides otherwise. }\end{array}$ \\
\hline Up to 18 months & $\begin{array}{l}\text { A decision on suspension of voting and representation rights will be considered } \\
\text { within three months after the declaration of noncooperation. }\end{array}$ \\
\hline Up to 24 months & $\begin{array}{l}\text { The procedure on compulsory withdrawal will be initiated within six months after } \\
\text { the decision on suspension. }\end{array}$ \\
\hline
\end{tabular}

$1 /$ Based on the procedures for dealing with members with overdue financial obligations to the Fund adopted by the Executive Board on August 17, 1989, as amended by Decision No. 12546-(01/84), adopted on August 22, 2001.

\section{CInternational Monetary Fund. Not for Redistribution}




\section{Annex II. Overdue Financial Obligations to the Poverty Reduction and Growth Trust (PRGT) Timetable of Remedial Measures}

\begin{tabular}{ll}
\hline Time after emergence of arrears & \multicolumn{1}{c}{ Action } \\
\hline & $\begin{array}{l}\text { Staff sends a cable urging the member to make the payment promptly; this } \\
\text { communication is followed up through the office of the concerned Executive } \\
\text { Immediately }\end{array}$ \\
& Director. The member's access to the Fund resources, including PRGT and HIPC \\
Resources is suspended
\end{tabular}

2 weeks

Management sends a communication to the Governor for the member stressing the seriousness of the failure to meet obligations to the Trust and urging full and prompt settlement.

1 month

The Managing Director notifies the Executive Board that an obligationn to the trust is overdue.

The Managing Director notifies the member that, unless the overdue obligations are settled promptly, a report concerning the arrears to the Trust will be issued to the Executive Board. The Managing Director would also consult with and recommend to the Executive Board that a communication concerning the member's situation should be sent to selected Fund Governors or to all Fund Governors in the event that the member has not improved its cooperation with the Fund.

2 months

A report is issued by the Managing Director to the Executive Board. The report will request that the Executive Board limit the member's use of PRGT resources.

The report is given substantive consideration by the Executive Board. A factual statement noting the existence and amount of arrears is posted on the member's country-specific page on the Fund's external website. The statement also indicates that the member's access to the Fund, including PRGT and HIPC

3 months resources, has been and will remain suspended until arrears are cleared. A press release is issued following the Executive Board's decision to limit the member's use of the PRGT resources. A similar press release will be issued following a decision to lift such limitation.

The Executive Board reviews its decision on limitation and may remove the member from the list of PRGT-eligible countries. Any reinstatement of the member on the list of PRGT-eligible countries will require a new decision of the Executive Board. A press release is issued following the Executive Board's decision to remove a member from the list of PRGT-eligible countries. A similar press release will be issued upon reinstatement of the member on the list.

A declaration of noncooperation with the PRGT may be issued by the Executive Board depending on the Board's assessment of the member's performance in the settlement of its arrears to the Trust and of its efforts, in consultation with the Fund, to follow appropriate policies for the settlement of its arrears. Upon a

12 months declaration of noncooperation, the Fund could decide to suspend the provision of technical assistance. The Managing Director may also limit technical assistance provided to a member, if it is in his judgment that assistance was not contributing adequately to the resolution of the problems associated with overdues to the Trust.

1/ Based on Decision No. 12545-(01/84) PRGF, adopted on August 22, 2001, as amended by Decision No. 13590-(05/99) ESF, November 23, 2005, effective January 5, 2006. 